\title{
SIFAT OPTIK, STRUKTUR KRISTAL DAN STRUKTUR MIKRO LAPISAN TIPIS ZnO:AI PADA SUBSTRAT KACA SEBAGAI BAHAN TCO
}

\author{
Wirjoadi, Bambang Siswanto \\ Pusat Teknologi Akselerator dan Proses Bahan, BATAN \\ Jl. Babarsari Kotak Pos 6101 ykbb, Yogyakarta 55281
}

\begin{abstract}
ABSTRAK
SIFAT OPTIK, STRUKTUR KRISTAL DAN STRUKTUR MIKRO LAPISAN TIPIS ZnO:AI PADA SUBSTRAT KACA SEBAGAI BAHAN TCO. Telah dilakukan karakterisasi sifat optik, struktur kristal dan struktur mikro lapisan tipis ZnO:Al hasil deposisi pada substrat kaca sebagai bahan Transparent Conducting Oxide (TCO) untuk sel surya dengan metode DC sputtering. Penelitian ini bertujuan untuk memperoleh hasil lapisan tipis ZnO:Al yang dapat digunakan sebagai bahan TCO untuk sel surya. Parameter sputtering optimum diperoleh pada kondisi suhu substrat $450^{\circ} \mathrm{C}$, tekanan gas $6 \times 10^{-2}$ torr dan waktu deposisi 1,5 jam. Sifat optik (transmitansi) lapisan tipis ZnO dan ZnO:Al masing-masing (62 - 80) \% dan (20 - 68) \% pada posisi panjang gelombang (400 - 800) nm. Struktur kristal lapisan tipis $\mathrm{ZnO}$ dan ZnO:Al terorientasi pada bidang (002) masing-masing dengan sudut hamburan $2 \theta=34,810^{\circ}$ dan $34,715^{\circ}$ atau terorientasi pada arah sumbu-c yang tegak lurus pada permukaan substrat. Hasil pengamatan struktur mikro dengan SEM, menunjukkan bahwa morfologi permukaan berbentuk butiran-butiran kecil yang terdistribusi cukup homogen dan mempunyai ketebalan sekitar 1,5 $\mu$ m untuk lapisan tipis ZnO, sedangkan untuk lapisan tipis ZnO:Al ketebalannya sekitar $1,0 \mu \mathrm{m}$.
\end{abstract}

\section{ABSTRACT}

OPTICAL PROPERTIES, CRYSTAL STRUCTURE AND MICRO STRUCTURE OF ZnO:AI THIN FILM ON THE GLASS SUBSTRATE FOR TCO MATERIAL. Characterization of optical properties, crystal structure and microstructure of ZnO:Al thin film deposited on glass substrate using dc sputtering method has been done. The aim of this research is to get a ZnO:Al thin film that can be used as a TCO materials for solar cell. The optimum sputtering parameter is obtained at $450^{\circ} \mathrm{C}$ of substrat temperature, $6 \times 10^{-2}$ torr of gas pressure and 1,5 hours of time deposition. At this condition the transmitance of $\mathrm{ZnO}$ and $\mathrm{ZnO}: \mathrm{Al}$ thin film at wave length (400 - 800) is (62 - 80) \% and (20 - 68) \%, respectively. The crystal structure of $\mathrm{ZnO}$ and $\mathrm{ZnO}: \mathrm{Al}$ is oriented at crystal plane (002) with scattering angle $2 \theta$ of $34.810^{\circ}$ and $34.715^{\circ}$. or on c-axis direction and upright on substrat surface. From mikrostructure observation using SEM is shown that the grains is distributed homogenously with the thickness of $\mathrm{ZnO}$ and $\mathrm{ZnO}: \mathrm{Al}$ thin film is about 1.5 $\mu \mathrm{m}$ and $1.0 \mu \mathrm{m}$ respectively.

\section{PENDAHULUAN}

Dada saat ini telah dikembangkan lapisan tipis $\mathrm{ZnO}$ :Al pada substrat kaca yang dapat digunakan sebagai bahan Transparent Conducting Oxide (TCO) untuk sel surya. Lapisan tipis $\mathrm{ZnO}$ yang dicampur dengan unsur Al merupakan salah satu jenis bahan TCO. Ada beberapa jenis lapisan tipis konduksi transparan antara lain yaitu $\mathrm{SnO}_{2}$, ITO dan TCO. $\mathrm{SnO}_{2}$ harga sangat murah, dan nilai resistivitas jauh lebih tinggi dibanding Indium Tin Oxide (ITO). ITO merupakan campuran dari $\mathrm{SnO}_{2}$ dan $\mathrm{In}_{2} \mathrm{O}_{3}$ dengan perbandingan $\mathrm{Sn}$ : In sekitar $5: 95$. Keunggulan ITO adalah resistivitas rendah, tetapi proses pembuatan In sangat mahal. Oleh karena itu pada saat ini dikembangkan lapisan tipis lain untuk lapisan konduktif transparan ${ }^{[1]}$.

Lapisan tipis ZnO:Al telah banyak diteliti karena aplikasinya begitu luas yaitu untuk peralatan permukaan gelombang akustik, sensor tekan, sensor gas, foto diode maupun sel surya. Bahan TCO ini selain mempunyai nilai resistivitas yang rendah dan harga murah juga mempunyai sifat-sifat optik yang baik. Dalam plasma hidrogen TCO juga mempunyai kestabilan arus dan tegangan yang tinggi, sehingga dapat ditumbuhkan dalam suhu rendah. Bahan $\mathrm{ZnO}$ adalah merupakan bahan semi konduktor tipe-N yang mempunyai struktur kristal Wurtzite. Lapisan tipis $\mathrm{ZnO}$ biasanya menunjukkan resistivitas rendah yang disebabkan oleh kekosongan (vakansi) oksigen dan penyisipan (interstisi) Zn karena komposisi yang nonstoichiometric ${ }^{[2,3]}$.

Dalam penelitian deposisi lapisan tipis ZnO:Al pada substrat kaca dengan metode DC sputtering diharapkan dapat diperoleh hasil lapisan tipis yang dapat digunakan sebagai bahan TCO untuk sel surya silikon 
amorf. Untuk mendapatkan lapisan tipis $\mathrm{ZnO}: \mathrm{Al}$ yang optimum, maka telah dilakukan variasi pembuatan target $\mathrm{ZnO}$ yang dicampur dengan beberapa persen berat $\mathrm{Al}$ dari $\mathrm{Al}_{2} \mathrm{O}_{3}$ yaitu 0,$53 ; 0,79 ; 1,05 ; 1,32$ dan $1,59 \%$. Sifatsifat lapisan tipis $\mathrm{ZnO}: \mathrm{Al}$ yang terdeposisi pada permukaan substrat kaca sangat tergantung dari parameter sputtering. Dalam hal ini parameter sputtering optimum diperoleh pada kondisi suhu substrat $450^{\circ} \mathrm{C}$, tekanan gas $6 \times 10^{-2}$ torr dan waktu deposisi 1,5 jam. ${ }^{[4,5]}$

Karakterisasi sifat optik transmitansi lapisan tipis ZnO:Al diukur menggunakan peralatan Spektrometer UVvis dan pengukuran sifat listrik resistansi digunakan voltmeter digital. Analisis struktur kristal dan penentuan ukuran sel satuan kristal dapat dilakukan dengan menggunakan pola difraksi sinar-X. Informasi yang diperoleh dari pola difraksi sinar-X adalah pola difraksi dari suatu benda uji yang hasilnya merupakan kurva intensitas versus sudut hamburan. Berdasarkan informasi sudut hamburan dapat ditentukan struktur kristalnya dan dari informasi intensitas hamburan dapat ditentukan posisi susunan atom.

Sel-sel satuan merupakan tempat atom logam yang memenuhi ruang tiga dimensi, maka bentuk geometrinya bila disusun selalu memenuhi ruang tiga dimensi. Dengan batasan ini, maka hanya ada tujuh bentuk atau sistem geometri kristal yang mungkin yaitu kubus, triklinik, monoklinik, orthorombik, tetragonal, rombhohedral dan heksagonal. ${ }^{(1)}$ Ukuran dan bentuk sel satuan dapat dinyatakan dalam panjang sumbu kristal a, b, c dan sudut diantara sumbu kristal $\alpha, \beta$, dan $\gamma$. Panjang sumbu dan sudut ini disebut tetapan kisi atau parameter kisi dari sel satuan. Apabila dalam ketujuh sistem kisi kristal tersebut ditambahkan titik-titik kisi yang lain pada posisi pusat tertentu, maka diperoleh tujuh sistem kisi kristal lainnya. Jika titik-titik pada kristal ini adalah kumpulan atom-atom (basis), maka yang dimaksud dengan struktur kristal adalah susunan atom-atom tertentu di dalam kristal yang dapat digambarkan sebagai gabungan antara kisi dan basis. ${ }^{[3]}$ Untuk pengamatan spektrum struktur kristal lapisan tipis ZnO:Al pada substrat kaca dilakukan dengan peralatan XRD, sedangkan untuk struktur mikro diamati menggunakan peralatan Scanning Electron Microscopy (SEM).

\section{TATA KERJA}

Dalam penelitian ini telah dilakukan beberapa tahapan proses yaitu preparasi cuplikan untuk substrat, pembuatan target $\mathrm{ZnO}$ yang dicampur dengan beberapa persen berat $\mathrm{Al}$ dari $\mathrm{Al}_{2} \mathrm{O}_{3}$ yang divariasi, persiapan peralatan untuk penelitian, proses pendeposisian lapisan tipis ZnO:Al pada substrat kaca. Kemudian karakterisasi lapisan tipis untuk pengukuran sifat optik (transmitansi) digunakan peralatan Spektrometer UV-vis dan pengukuran sifat listrik (resistansi) digunakan voltmeter digital. Selanjutnya karakterisasi struktur kristal digunakan difraksi sinar-X (XRD) dan untuk struktur mikro digunakan SEM.

\section{Persiapan pembuatan substrat dan target}

Bahan yang akan digunakan untuk substrat adalah kaca preparat yang dipotong-potong dengan ukuran $1 \mathrm{~cm} \times 2 \mathrm{~cm}$. Substrat kaca tersebut dicuci dengan deterjen, kemudian dengan alkohol yang digetarkan menggunakan peralatan ultrasonic cleaner. Setelah bersih, substrat dibersihkan lagi dengan tissue, dikeringkan dengan pemanas (oven), kemudian dibersihkan lagi dengan aceton, selanjutnya dimasukkan dalam pembungkus plastik klip. Bahan yang akan digunakan untuk target yaitu serbuk ZnO $(99,9 \%)$ dicampur dengan beberapa persen berat $\mathrm{Al}$ dari $\mathrm{Al}_{2} \mathrm{O}_{3}$ yaitu 0,$53 ; 0,79 ; 1,05 ; 1,32$ dan 1,59\%. Target $\mathrm{ZnO}$ :Al ini telah dibuat berbentuk pelet berdiameter $60 \mathrm{~mm}$, tebal $2 \mathrm{~mm}$, lalu ditekan dan dipres dengan beban $50 \mathrm{~N}$. Sebelum dilakukan pengepresan, serbuk $\mathrm{ZnO}$ yang dicampur dengan beberapa persen berat $\mathrm{Al}$ dari $\mathrm{Al}_{2} \mathrm{O}_{3}$ diaduk dulu supaya kedua campuran bahan tersebut bisa merata atau homogen. Setelah target dicetak menjadi pelet, kemudian dipanaskan pada suhu $600{ }^{\circ} \mathrm{C}$ selama 2 jam.

\section{Persiapan Peralatan Penelitian}

Dalam penelitian ini peralatan yang digunakan untuk deposisi lapisan tipis ZnO:Al pada substrat kaca adalah peralatan DC sputtering, seperti ditunjukkan pada Gambar 1 yang terdiri dari :

a). Reaktor Plasma

1. Tabung reaktor dari stainless steel yang dilengkapi dengan 2 elektrode dan jendela kaca.

2. Pemegang target dan substrat. 
3. Catu daya arus searah.

4. Alat ukur arus, tegangan dan vakum.

5. Pompa vakum rotari dan turbo.

6. Pemanas substrat dan pendingin target.

7. Gas Argon.

b). Alat-alat karakterisasi

1. Karakterisasi sifat-sifat optik (transmitansi) dengan spektrofotometer UV-vis

2. Karakterisasi sifat listrik (resistansi) digunakan digital volt meter.

3. Karakterisasi struktur kristal lapisan tipis digunakan difraksi Sinar-X (XRD).

4. Karakterisasi struktur mikro yaitu morfologi permukaan dan ketebalan lapisan tipis digunakan peralatan SEM (Scanning Electron Microscope).

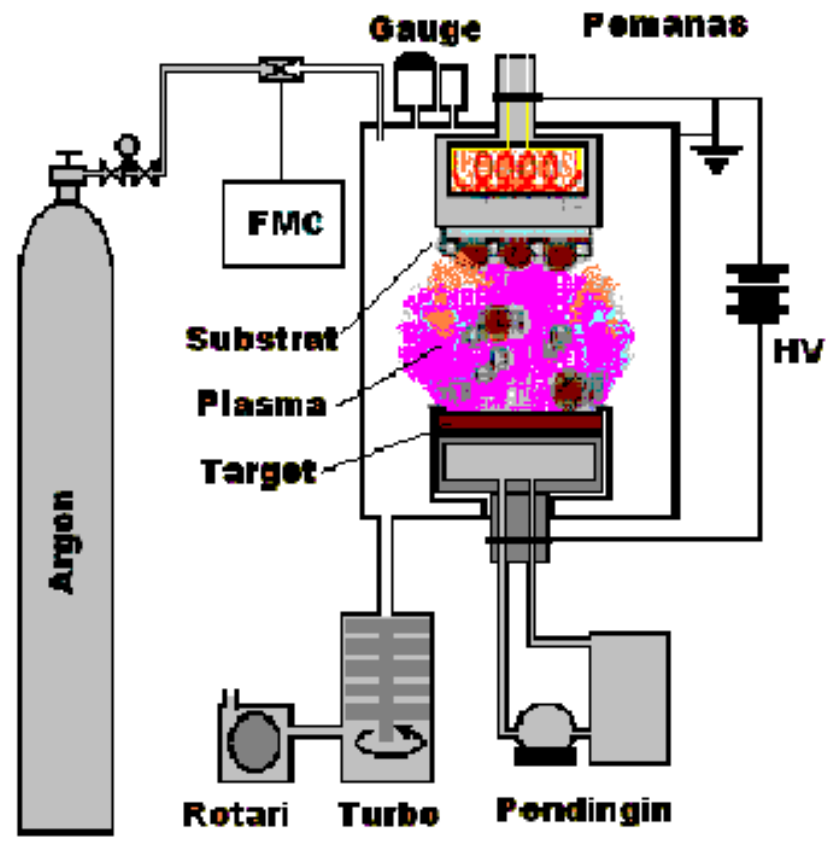

Gambar 1. Skema Sistem Deposisi Sputtering

\section{Proses Pelaksanaan Penelitian}

Proses deposisi lapisan tipis ZnO:Al pada substrat kaca untuk sel surya telah dilakukan dengan metode $D C$ sputtering dan skema peralatan seperti yang ditampilkan pada Gambar 1. Dalam proses deposisi lapisan tipis $\mathrm{ZnO}: \mathrm{Al}$ ini telah dibuat variasi target $\mathrm{ZnO}$ yang dicampur dengan beberapa prosen berat $\mathrm{Al}$ dari $\mathrm{Al}_{2} \mathrm{O}_{3}(99,9 \%)$ yaitu 0,$53 ; 0,79 ; 1,05 ; 1,32$ dan $1,59 \%$. Mula-mula target dari ZnO:Al dipasang pada katode dan substrat kaca diletakkan pada anode. Udara di dalam tabung reaktor divakumkan dengan pompa rotari dan turbo yang tekanannya sampai dengan $10^{-5}$ torr dapat digunakan untuk membersihkan partikel-partikel yang tidak dikehendaki. Kemudian gas argon dialirkan melalui kran, sehingga tekanan gas di dalam tabung reaktor akan naik menjadi $10^{-2}$ torr. Pada bagian katoda (tempat target) didinginkan dengan air pendingin yang disirkulasi supaya suhu pada target tidak naik, karena tertumbuk ion argon. Selanjutnya pada bagian anoda (tempat substrat) justru dipanaskan yang berfungsi untuk memperbesar frekuensi getaran atom substrat. Apabila penyedia daya tegangan tinggi DC dihidupkan, maka gas argon yang ada pada celah elektroda akan terionisasi. Pada saat gas terionisasi, maka ion argon menumbuki target $\mathrm{ZnO}: \mathrm{Al}$ dan atom-atom target akan terpercik ke substrat kaca. Lapisan tipis yang terdeposisi pada substrat kaca ini tergantung pada parameter sputtering, Pada eksperimen awal sebelumnya, kondisi optimum parameter sputtering telah diketahui yaitu pada suhu substrat $450{ }^{\circ} \mathrm{C}$, tekanan gas 6 x $10^{-2}$ torr, waktu deposisi 1,5 jam, daya sekitar $40 \mathrm{~W}$ dan jarak elektrode $2 \mathrm{~cm}$. Hasil deposisi lapisan tipis ZnO:Al 
diperoleh nilai optimum atau resistansi paling rendah $R=(45,20 \pm 0,49) \Omega$ pada target dengan prosen berat 1,05 $\%$. Kemudian target dengan prosen berat $1,05 \%$ ini yang akan digunakan untuk eksperimen selanjutnya.

\section{HASIL DAN PEMBAHASAN}

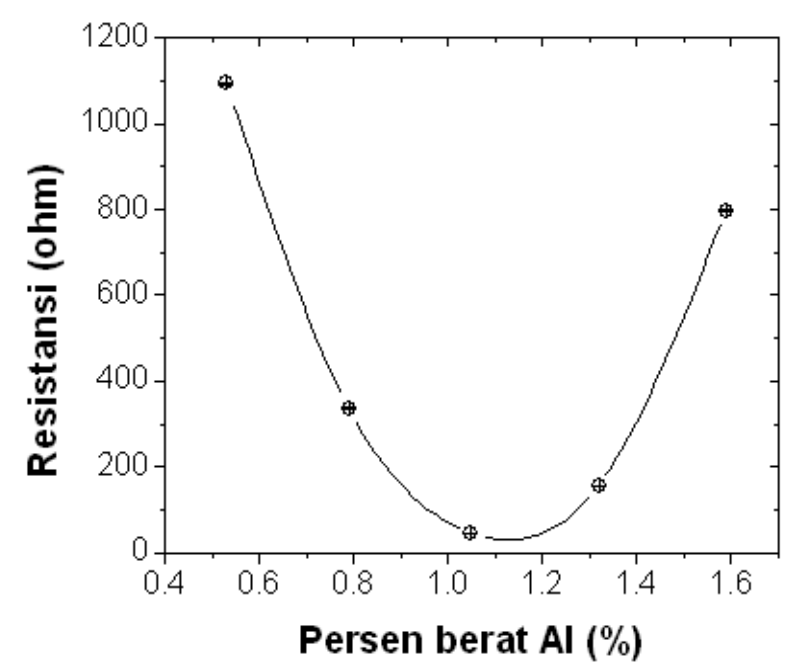

Gambar 2. Resistansi lapisan tipis $\mathrm{ZnO}: \mathrm{Al}$ sebagai fungsi target persen berat Al.

Pada Gambar 2 ditampilkan hasil pengukuran nilai resistansi lapisan tipis $\mathrm{ZnO}: \mathrm{Al}$ variasi persen berat $\mathrm{Al}$ 0,$53 ; 0,79 ; 1,05 ; 1,32$ dan $1,59 \%$ pada kondisi suhu substrat $450^{\circ} \mathrm{C}$, tekanan gas $6 \times 10^{-2}$ torr dan waktu deposisi $1,5 \mathrm{jam}$. Berdasarkan hasil pengukuran tersebut dapat dilihat bahwa nilai resistansi lapisan tipis $\mathrm{ZnO}$ :Al menurun dari $R=(1.094,19 \pm 3,33) \Omega$ untuk target dengan prosen berat Al 0,53 \% hingga mencapai nilai resistansi optimum sebesar $R=(45,20 \pm 0,49) \Omega$ pada target dengan prosen berat Al 1,05\%. Hasil nilai resistansi akan naik lagi hingga $R=(797,24 \pm 1,60) \Omega$ dengan bertambahnya prosentase berat Al $1,59 \%$. Hal ini terjadi karena pada saat tingkat dopan meningkat, maka atom-atom dopan akan lebih banyak menempati pada letak kisi atom Zn sehingga lebih banyak menghasilkan pembawa muatan. Akan tetapi setelah tingkat konsentrasi dopan tertentu, atom-atom dopan dalam butiran kristal dan batas-batas butir cenderung mengalami kejenuhan sehingga mengakibatkan menurunnya mobilitas lapisan $\mathrm{ZnO}: \mathrm{Al}$. Untuk eksperimen selanjutnya dipakai target dengan prosen berat Al yang mempunyai resistansi rendah yaitu $1,05 \%$.

Dalam penelitian ini untuk mendapatkan lapisan tipis $\mathrm{ZnO}$ dan $\mathrm{ZnO}$ :Al pada substrat kaca yang digunakan sebagai TCO mempunyai sifat-sifat listrik (resistansi) dan sifat-sifat optik (transmitansi) yang optimum tergantung pada parameter sputtering. Karakterisasi sifat-sifat listrik (resistansi) dari lapisan tipis $\mathrm{ZnO}$ dan $\mathrm{ZnO}: \mathrm{Al}$ pada substrat kaca masing-masing diperoleh sekitar $R=(14.456 \pm 0,20) \mathrm{k} \Omega$ dan $\mathrm{R}=(45,20 \pm 0,49) \Omega$. Hasil dari pengukuran karakterisasi sifat-sifat optik (transmitansi) lapisan tipis $\mathrm{ZnO}$ dan $\mathrm{ZnO}$ :Al pada substrat kaca sebagai bahan TCO diperoleh optimum pada suhu substrat $450^{\circ} \mathrm{C}$, tekanan gas $6,0 \times 10^{-2}$ Torr, lama waktu deposisi 1,5 jam dengan spektrofotometer UV-vis ditunjukkan pada Gambar 3.

Pada Gambar 3 menyajikan karakterisasi sifat optik (transmitansi) lapisan tipis $\mathrm{ZnO}$ dan ZnO:Al yang masing-masing diperoleh hasil sekitar (62 - 80) \% dan (20 - 68) \% pada posisi panjang gelombang (400 - 800) nm. Nilai transmitansi lapisan tipis $\mathrm{ZnO}$ lebih besar bila dibandingkan dengan transmitansi lapisan tipis $\mathrm{ZnO}: \mathrm{Al}$, karena lapisan tipis $\mathrm{ZnO}$ mempunyai sifat tembus cahaya yang cukup besar, sedangkan Al untuk dopan $\mathrm{ZnO}$ tidak mempunyai sifat tembus cahaya tetapi bisa memantulkan cahaya. Dengan demikian lapisan tipis $\mathrm{ZnO}$ yang didopan dengan sedikit Al akan berkurang nilai transmitansinya. Berdasarkan karakterisasi sifat-sifat listrik (resistansi) dan sifat-sifat optik (transmitansi) tersebut, maka lapisan tipis ZnO:Al ini bisa diaplikasikan sebagai TCO.

Dalam penelitian ini juga dilakukan karakterisasi struktur kristal lapisan tipis $\mathrm{ZnO}$ dan $\mathrm{ZnO}: \mathrm{Al}$ dengan difraksi Sinar-X (XRD). Hasil karakterisasi struktur kristal lapisan tipis ZnO dan ZnO:Al, pada substrat kaca 
dengan XRD, pada suhu substrat $450^{\circ} \mathrm{C}$, tekanan gas $6,0 \times 10^{-2}$ torr dan waktu deposisi 1,5 jam masing-masing ditunjukkan pada Gambar 4 dan Gambar 5.

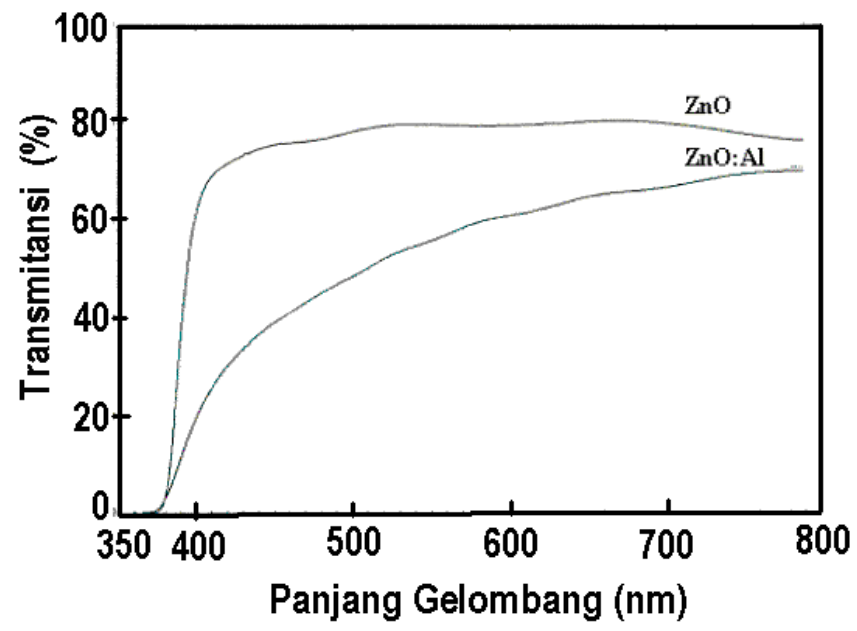

Gambar 3. Hubungan transmitansi vs panjang gelombang untuk lapisan tipis $\mathrm{ZnO}$ dan $\mathrm{ZnO}: \mathrm{Al}$ pada substrat kaca dengan spektrofotometer UV-vis.

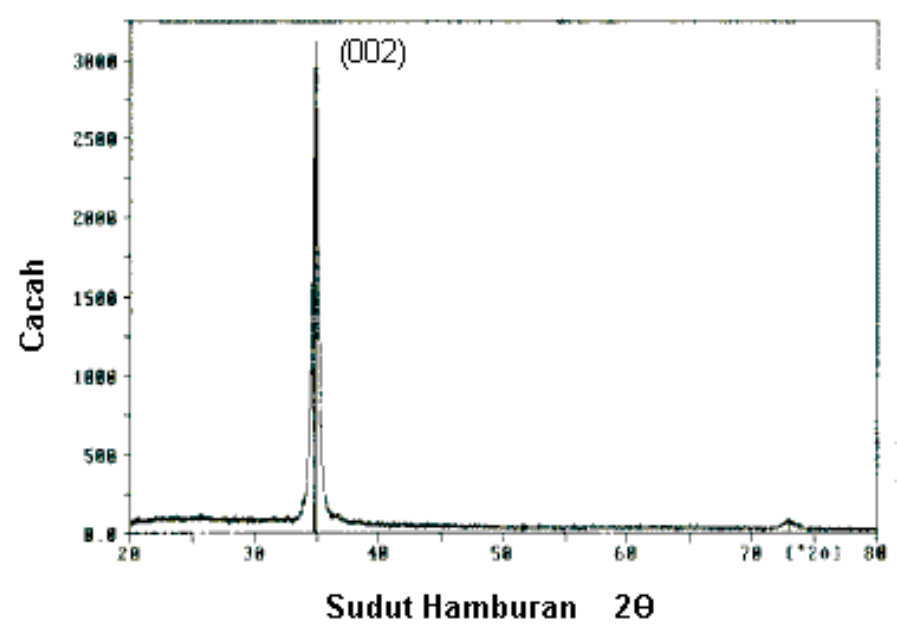

Gambar 4. Struktur kristal lapisan tipis ZnO murni dalam pola difraksi Sinar-X. 


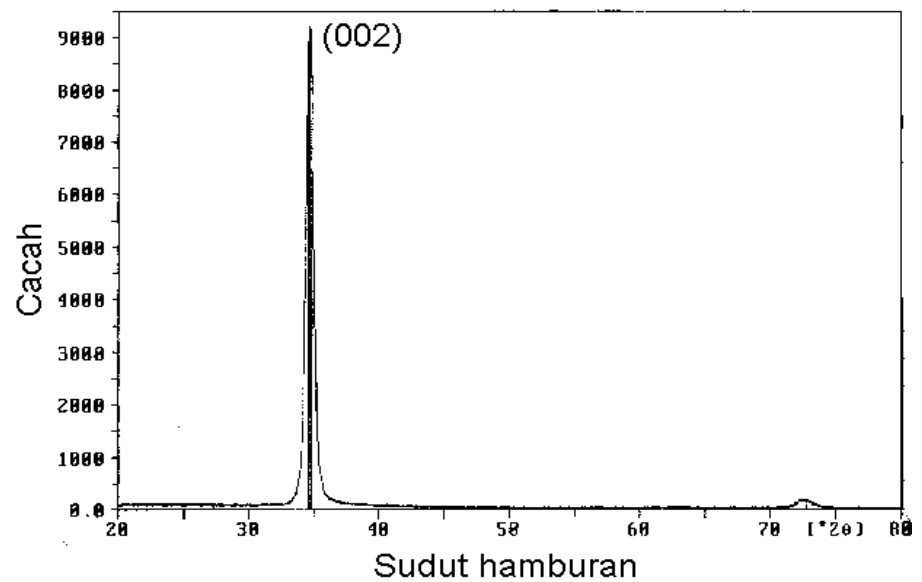

Gambar 5. Sruktur kristal lapisan tipis ZnO : Al (dengan prosen berat Al 1,05 \%) dalam pola difraksi Sinar-X.

Berdasarkan analisis data pola difraksi Sinar-X telah memperlihatkan bahwa puncak pertumbuhan kristal $\mathrm{ZnO}$ murni pada Gambar 4 terorientasi pada bidang (002) dengan sudut $2 \theta=34,810^{\circ}$ dan puncak pertumbuhan kristal ZnO:Al pada Gambar 5 juga terorientasi pada bidang (002) dengan sudut $2 \theta=34,715^{\circ}$. Hasil analisis struktur kristal pada Gambar tersebut dapat diketahui bahwa ZnO dan ZnO:Al adalah suatu kristal dan menunjukkan bahwa arah pertumbuhannya terorientasi pada sumbu-c yang tegak lurus pada permukaan substrat.

Intensitas puncak (cacah) pola difraksi Sinar-X lapisan tipis ZnO murni Gambar 4 adalah sekitar 2.777 cacah dengan setengah lebar puncak maksimum $(\mathrm{FWHM})=0,16^{\circ}$, sedangkan untuk lapisan tipis ZnO:Al Gambar 5 sekitar 9.082 cacah dengan setengah lebar puncak maksimum $(F W H M)=0,18^{\circ}$. Intensitas puncak (cacah) pada Gambar 5 lebih tinggi dibandingkan dengan intensitas puncak (cacah) pada Gambar 4, hal ini menunjukkan bahwa struktur kristal lapisan tipis ZnO:Al lebih teratur bila dibandingkan dengan lapisan tipis $\mathrm{ZnO}$.

Dalam penelitian ini juga dilakukan pengamatan struktur mikro atau morfologi permukaan lapisan tipis $\mathrm{ZnO}$ murni dan ZnO:Al (persen berat Al 1,05\% Al) pada kondisi optimum, yaitu pada suhu substrat $450{ }^{\circ} \mathrm{C}$, tekanan $6 \mathrm{x}$ $10^{-2}$ torr dan waktu deposisi $1,5 \mathrm{jam}$.

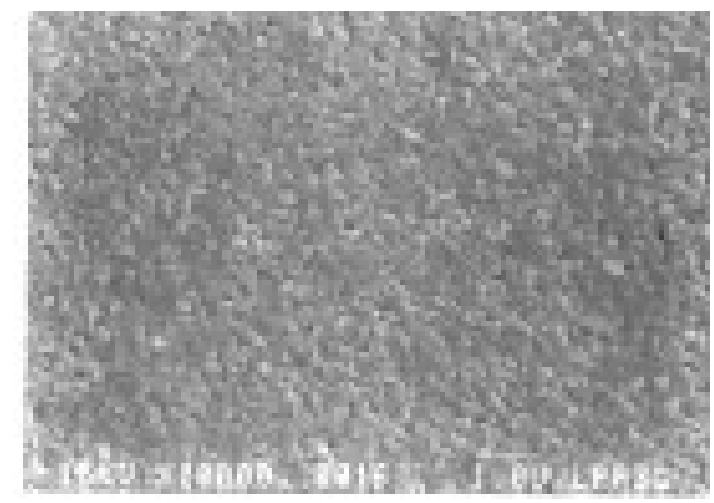

(a). $\mathrm{ZnO}$ 


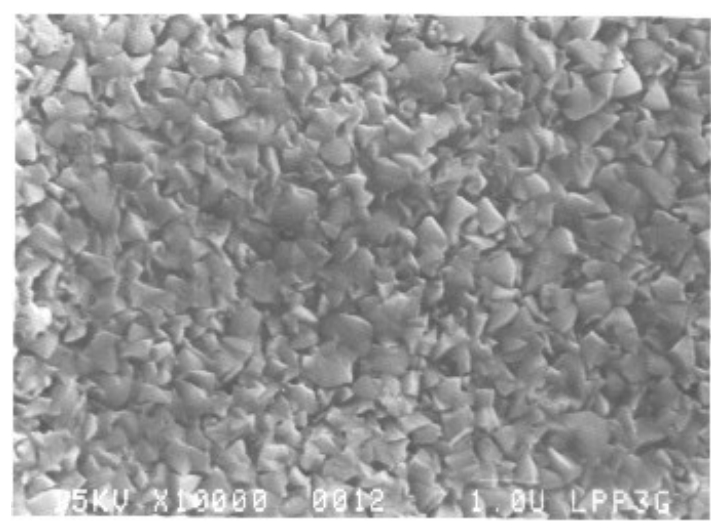

(b). $\mathrm{ZnO}: \mathrm{Al}$.

Gamb.ar 6. Hasil struktur mikro, morfologi permukaan lapisan tipis dengan SEM (perbesaran 10.000 kali).

Morfologi permukaan lapisan tipis $\mathrm{ZnO}$ dan $\mathrm{ZnO}: \mathrm{Al}$ yang terdeposit pada permukaan substrat kaca dikarakterisasi menggunakan SEM dan hasil pengamatan SEM tersebut berupa foto-foto yang ditampilkan pada Gambar 6. Hasil analisis SEM untuk lapisan tipis ZnO pada Gambar 6(a) memperlihatkan adanya keseragaman struktur butir kecil-kecil yang mempunyai morfologi permukaan cukup merata. Hasil analisis SEM lapisan ZnO:Al pada Gambar 6(b) memperlihatkan bahwa ukuran butirnya tampak lebih besar bila dibandingkan dengan ukuran butir pada lapisan $\mathrm{ZnO}$ dan kedua morfologi permukaan tersebut terdistribusi cukup homogen Berdasarkan hasil pengamatan SEM yang ditampilkan pada Gambar 6(a) dan 6(b) terlihat bahwa prosentase berat dopan Al (1,05 \%) akan mempengaruhi pertumbuhan inti dari butir-butir kecil yang mengakibatkan terbentuknya butiran-butiran yang lebih besar. Hasil foto dari SEM tampang lintang lapisan tipis $\mathrm{ZnO}$ yang terdeposit pada substrat kaca dengan ketebalan lapisan 1,5 $\mu \mathrm{m}$ ditampilkan pada Gambar 7(a) dan tampang lintang lapisan tipis ZnO:Al yang terdeposit pada substrat kaca dengan ketebalan lapisan 1,0 $\mu$ m ditampilkan pada Gambar 7(b).

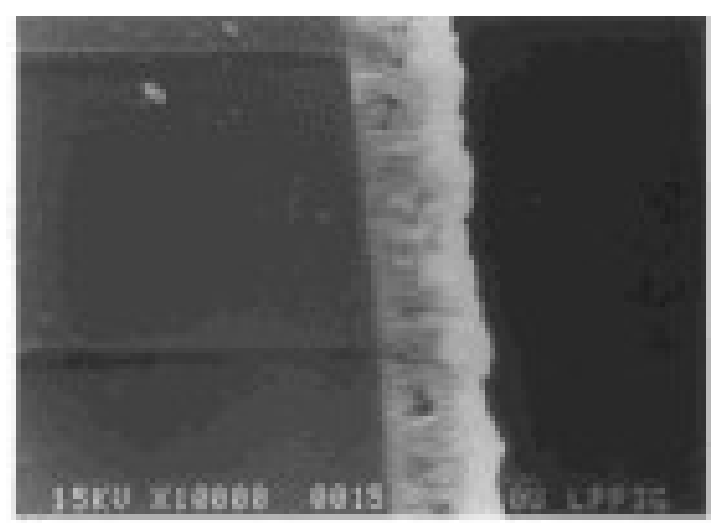

(a). $\mathrm{ZnO}$ 


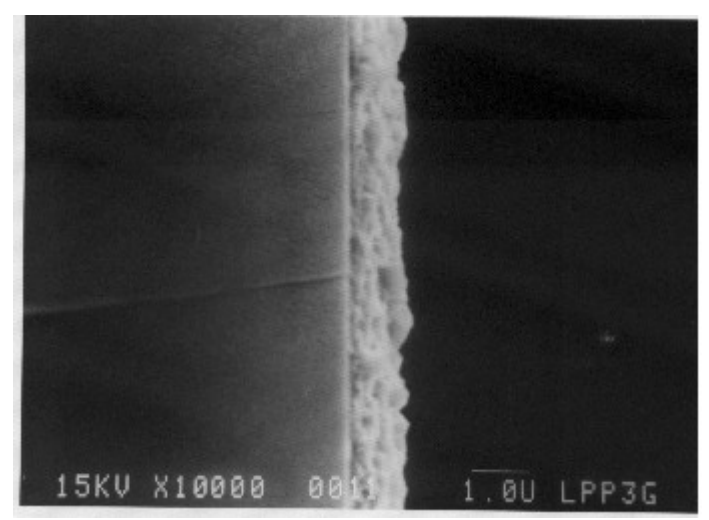

(b). $\mathrm{ZnO}: \mathrm{Al}$

Gambar 7. Hasil foto SEM struktur mikro, tampang lintang, (a). ketebalan lapisan 1,5 $\mu \mathrm{m}$, (b). ketebalan lapisan $1 \mu \mathrm{m}$ (perbesaran 10.000 kali).

\section{KESIMPULAN}

1. Hasil karakterisasi sifat listrik resistansi lapisan tipis $\mathrm{ZnO}: \mathrm{Al}$ pada substrat kaca dengan ohm meter digital diperoleh nilai resistansi minimum sebesar $R=(45,20 \pm 0,49) \Omega$ untuk dopan dengan prosen berat Al $1,05 \%$.

2. Hasil karakterisasi sifat optik transmitansi lapisan tipis $\mathrm{ZnO}$ dan $\mathrm{ZnO}: \mathrm{Al}$ pada substrat kaca menggunakan spektrofotometer UV-vis diperoleh hasil nilai transmitansi optimum masing-masing sekitar $(62-80) \%$ dan (20-68) \% dan ini dicapai pada rentang panjang gelombang (400-800) nm.

3. Hasil karakterisasi struktur kristal lapisan tipis $\mathrm{ZnO}$ dan $\mathrm{ZnO}$ :Al terorientasi pada bidang (002), masing- masing dengan sudut hamburan $2 \theta=34,810^{\circ}$ dan $34,715^{\circ}$ atau terorientasi pada arah sumbu-c yang tegak lurus pada permukaan substrat.

4. Hasil karakterisasi struktur mikro dengan SEM, menunjukkan bahwa morfologi permukaan berbentuk butiranbutiran kecil dari lapisan $\mathrm{ZnO}$ dan berbentuk butiran-butiran lebih besar untuk lapisan $\mathrm{ZnO}$ :Al yang secara keseluruhan terdistribusi cukup merata atau homogen.

5. Hasil karakterisasi tampang lintang dengan SEM diperoleh ketebalan sekitar 1,5 $\mu \mathrm{m}$ untuk lapisan tipis $\mathrm{ZnO}$, sedangkan untuk lapisan tipis ZnO:Al ketebalannya sekitar 1,0 $\mu \mathrm{m}$. 


\section{DAFTAR PUSTAKA}

1. KATSUYA TABUCHI, WILSON W. WENAS, MASAHIRO YOSHINO, A. YAMADA, "Optimation of ZnO Film for Amorphous Silicon Solar Cells", $11^{\text {th }}$ European Photo voltaic Solar Energy Conference and Exhibition, Montreux, Switzerland, 12-16 October 1992.

2. KATSUYA TABUCHI, WILSON W. WENAS, AKIRA YAMADA, Optimization of ZnO Film for Amorphous Silicon Solar Cells, Jpn, J. Appl. Phys, Vol, 33332 (1993), Part I, No. 9A, 3764-3769.

3. K. TAKAHASHI AND M. KONAGAI, Amorphous Silicon Solar Cells, Nort Oxford Academic Publishers Ltd, (1986).

4. MAKOTO KONAGAI, "Device Physics and Optimum Desaign of (a-Si) Solar Cell", $5^{\text {th }}$ "Sunshine" Workshop on Solar Cells, December 8-9, (1992), Tokyo, Japan.

5. TADATSUGU MINAMI, HIDEO SONOHARA, SHINZO TAKATA AND ICHIRO FUKUDA, LOW Temperature Formation of Textured ZnO Transparent Electrodes by Magnetron Sputtering, J. Vac. Sci. Technol. A 13 (3), May/Jun (1995). 